\title{
Structure and Biological Activity of Neopeptins A, B and C, Inhibitors of Fungal Cell Wall Glycan Synthesis
}

\author{
Makoto Ubukata, Masakazu Uramoto, Jun Uzawa \\ and Kiyoshi IsONO* \\ Antibiotics Laboratory, RIKEN (The Institute of Physical and Chemical Research), \\ Wako-shi, Saitama 351-01, Japan \\ Received June 6, 1985
}

\begin{abstract}
The antifungal antibiotics, neopetins $\mathrm{A}(\mathbf{1}), \mathrm{B}(2)$ and $\mathrm{C}(3)$, were found to be cyclic lipopeptides containing unusual amino acids, their structures being elucidated on the basis of chemical and spectroscopic evidence. They inhibited mannoprotein and $\beta$-1,3-glucan synthetases from Saccharomyces cerevisiae. The structure--biological activity relationship is discussed.
\end{abstract}

Neopeptins A and B were isolated from the culture filtrate of Streptomyces sp. during our screening for inhibitors of microbial cell wall biosynthesis. ${ }^{1)}$ During the study ${ }^{2)}$ of the structure of neopeptins A (1) and B (2), we isolated an additional active component named neo- peptin C (3).

This paper deals with the isolation of $\mathbf{3}$, the structural elucidation of neopeptins A (1), B (2), and C (3), and the structure-activity relationship among the related compounds.

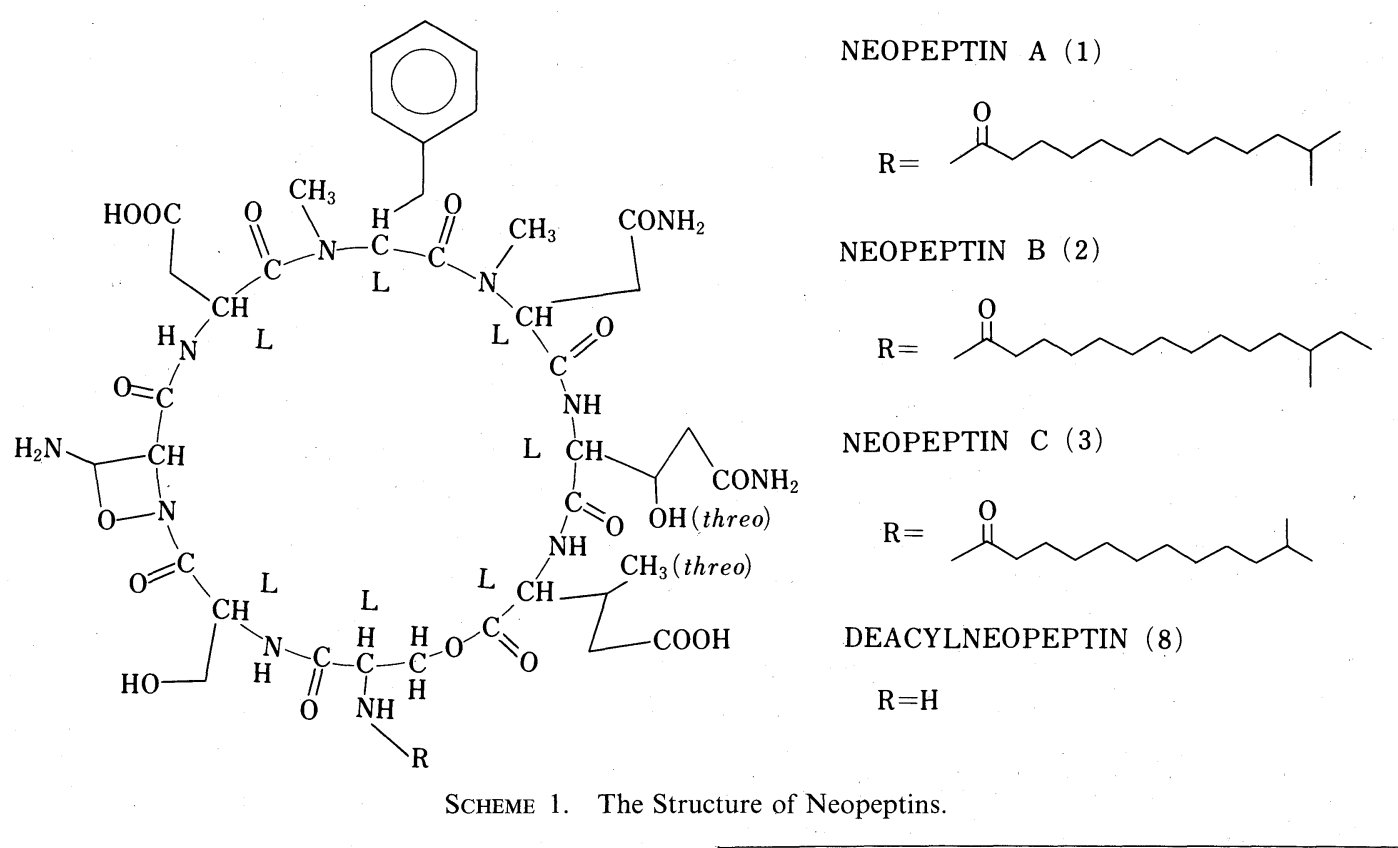

\section{Isolation of neopeptin $C$}

Isolation of the minor component 3 from the neopeptin comolex was achieved by pre- parative HPLC using a PrepPAC-500/C 18 column with the following solvent system: buffer $(1 \%$ triethylamine-phosphoric acid, 
$\mathrm{pH} 3)$-acetonitrile (55:45 v/v). From the first peak, 3 was obtained as a white powder after desalting by preparative HPLC (adsorbed from water and then eluted with methanol). Further purification was done by Nucleosil $5 \mathrm{C}_{18}$ developed with $60 \%$ methanol. The sec- ond and the third peaks gave $\mathbf{1}$ and $\mathbf{2}$, respectively.

\section{Constituents of neopeptins}

Acid hydrolysis of $\mathbf{1}$ gave seven amino acids and a fatty acid as shown in Scheme 2. All

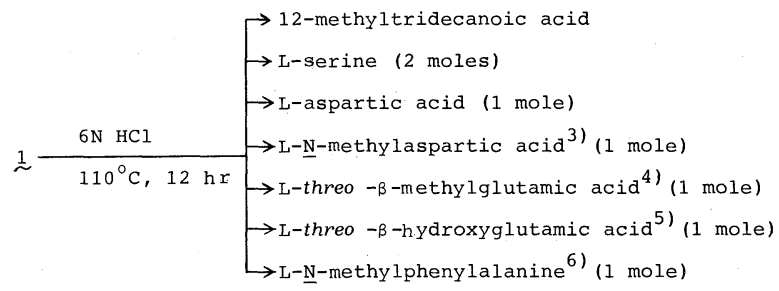

SCHEME 2.

these amino acids were identified by ${ }^{1} \mathrm{H}$ NMR, GC/MS analysis of corresponding TMS derivatives, and finally by comparing with authentic samples.

The fatty acid was esterified with diazomethane and analyzed by GC/MS (Fig. 1a). As shown in Fig. 1a, a molecular ion peak $\left(m / z 242 \mathrm{M}^{+}\right)$of the methyl ester indicated a $\mathrm{C}_{14}$ fatty acid, and the intense ion $m / z 199$ $\left(\mathrm{M}-\mathrm{C}_{3} \mathrm{H}_{7}\right)^{+}$indicated the iso-structure. The spectrum was superimposable on that of authentic methyl 12-methyltridecanoate. ${ }^{7)}$ Acid hydrolysis of $\mathbf{2}$ and $\mathbf{3}$ gave the identical amino acids to those from 1 . A fatty acid from 2 was found to be 12-methyltetradecanoic acid. ${ }^{7)}$ As shown in Fig. 1b, the spectrum of the methyl ester showed the peaks $m / z 256 \mathrm{M}^{+}, m / z 199$ $\left(\mathrm{M}-\mathrm{C}_{4} \mathrm{H}_{9}\right)^{+}, m / z 227\left(\mathrm{M}-\mathrm{C}_{2} \mathrm{H}_{5}\right)^{+}$and $m / z$ $225\left(\mathrm{M}-\mathrm{OCH}_{3}\right)^{+}$.

The abundance of the fragment ion $m / z 199$ $\left(\mathrm{M}-\mathrm{C}_{4} \mathrm{H}_{9}\right)^{+}$suggested branching at $\mathrm{C}-12$. The anteiso structure was further supported by the unusual fragment ion abundance $\left[\left(\mathrm{M}-\mathrm{C}_{2} \mathrm{H}_{5}\right)^{+}>\left(\mathrm{M}-\mathrm{OCH}_{3}\right)^{+}\right] .{ }^{8)} \quad$ Authentic methyl 12-methyltetradecanoate gave an essentially identical spectrum to that in Fig. 1 b.

A fatty acid from 3 was determined to be 11methyldodecanoic acid. Figure 1c shows the spectrum of the methyl ester, indicating the ions $\dot{m} / z 228 \mathrm{M}^{+}, m / z 197\left(\mathrm{M}-\mathrm{OCH}_{3}\right)^{+}$and $m / z 185\left(\mathrm{M}-\mathrm{C}_{3} \mathrm{H}_{7}\right)^{+}$. The fragmentation pattern of the spectrum is similar to that of meth- yl 12-methyltridecanoate.

Subtraction of the sum $\left(\mathrm{C}_{50} \mathrm{H}_{77} \mathrm{~N}_{9} \mathrm{O}_{17}\right)$ of the seven amino acids and the fatty acid linked by eight amide bonds $\left(v_{\max }^{\mathrm{KBr}} 1650,1530 \mathrm{~cm}^{-1}\right)$ and one lactone bond $\left(v_{\max }^{\mathrm{KBr}} 1740 \mathrm{~cm}^{-1}\right)$ plus two primary amides $\left(\delta_{\mathrm{H}} 6.80,6.88,7.25\right.$, $7.40 \mathrm{ppm}$ in DMSO- $d_{6}$ at $400 \mathrm{MHz}$ ) from the molecular formula of $\mathbf{1}\left(\mathrm{C}_{53} \mathrm{H}_{81} \mathrm{~N}_{11} \mathrm{O}_{19}\right)$ gave a formula $\left(\mathrm{C}_{3} \mathrm{H}_{4} \mathrm{~N}_{2} \mathrm{O}_{2}\right)$ for an amino acid residue, which accounts the basicity of 1 . Although the intact labile basic amino acid could not be isolated, the structure was deduced to be 3-amino-2-oxazetidine-4-carboxylic acid (Aoc) from the following chemical and spectral evidence: (a) hydrogenation of 1 over $\mathrm{PtO}_{2}$ at $4 \mathrm{~atm}$, followed by acid hydrolysis gave a small amount of diaminopropionic acid in addition to the seven amino acids (Fig. 2); (b) the SIMS spectrum (Scheme 3) of 4 indicated fragment ions yielded by a loss of formamide ( $-45 \mathrm{amu})$; (c) ${ }^{13} \mathrm{C} \mathrm{NMR}$ data $(\beta$-carbon atom of Aoc, $\delta 71.4 \mathrm{ppm}$, $J_{\mathrm{CH}}=150 \mathrm{~Hz}$, in DMSO- $d_{6}$ at $25.05 \mathrm{MHz}$ ) are consistent with a four-membered ring ${ }^{9}{ }^{9}$ (d) the apparent basicity ( $\mathrm{pKa}^{\prime}$ 9.5) of $\mathbf{1}$ and negative ferric chloride test result exclude the possibility of oxime; and (e) the presence of a doublet attributable to a proton of Aoc excludes an epoxide possibility. Although the stereochemistry of Aoc remains to be resolved, the coupling constants $(J=3.6 \mathrm{~Hz}$ and $5.4 \mathrm{~Hz})$ between the $\alpha$ and $\beta$ protons of the four-mem- 

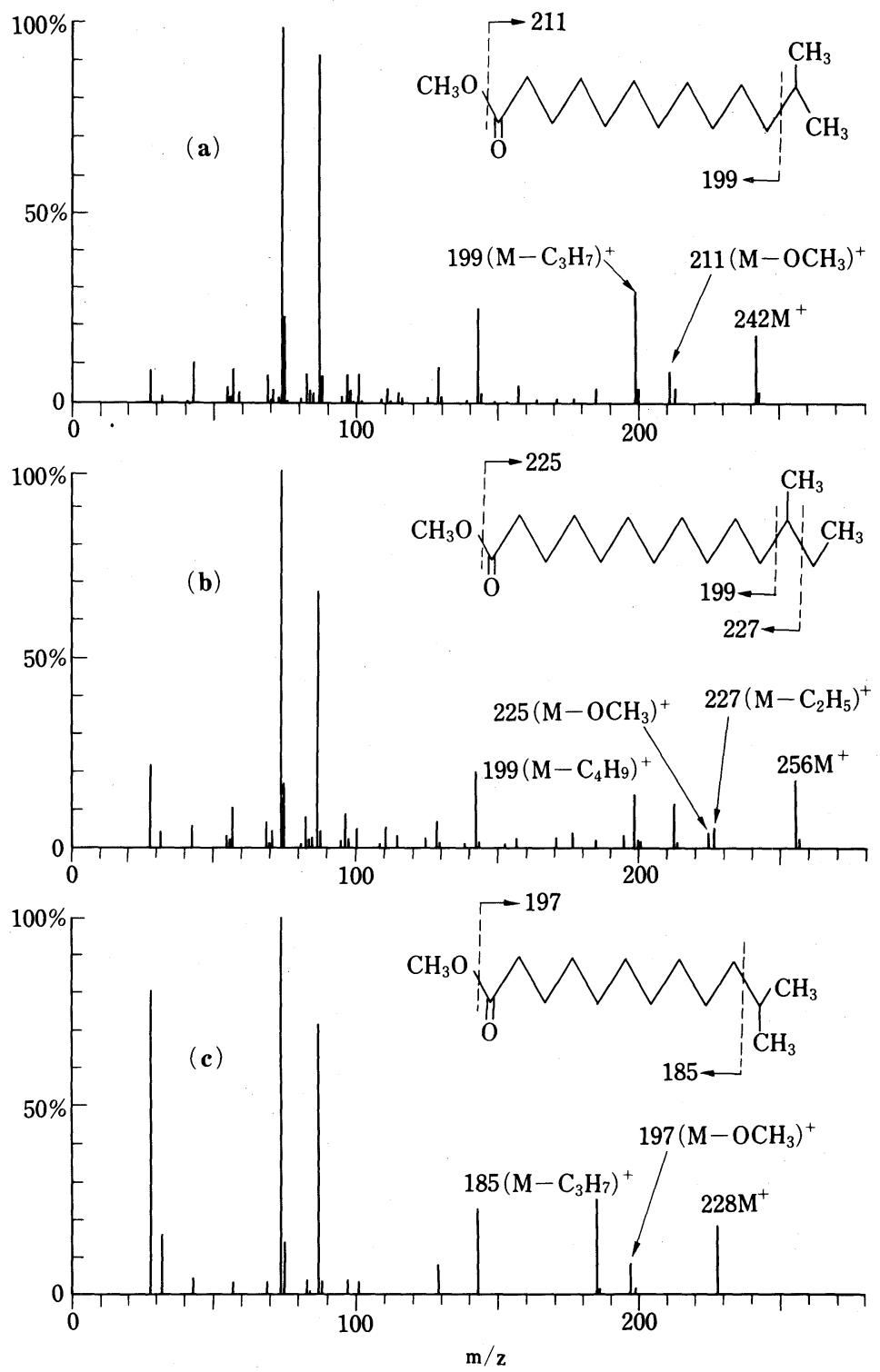

FIG. 1. GC/EIMS Spectra of Methyl Esters of the Side-chain Fatty Acids.

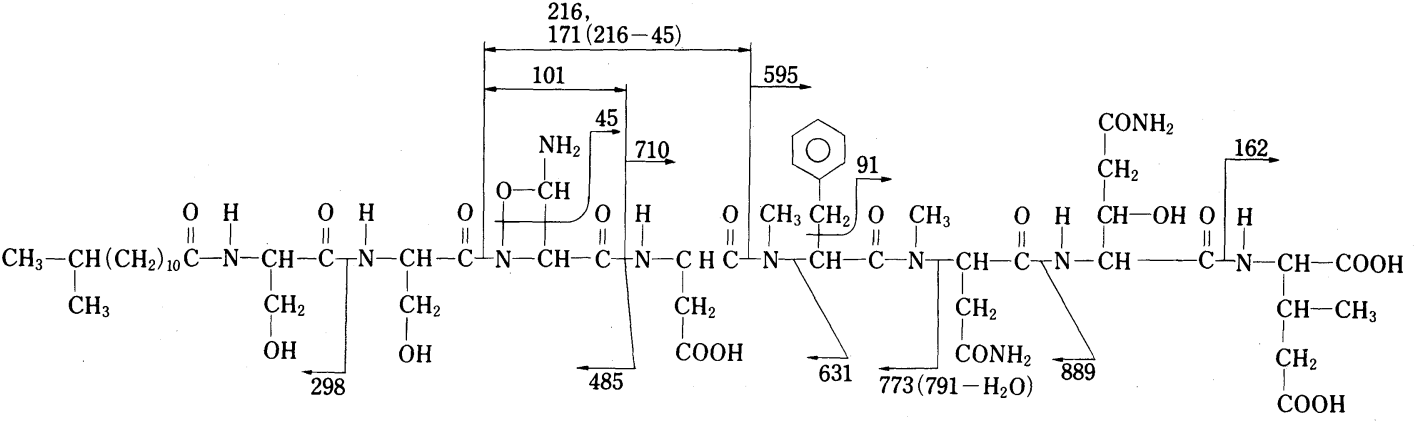

SCHEME 3. Analysis of the Open-chain Acid 4 by SIMS. 
bered ring suggest a trans relationship, ${ }^{10)}$ as shown in Fig. 2.

Open chain acid (4) and the amino acid sequence

Hydrolysis of 1 by $0.035 \mathrm{~N} \mathrm{NaOH}$ gave an open-chain acid (4), $m / z 1194(\mathrm{M}+\mathrm{H})^{+}$and $m / z 1216(\mathrm{M}+\mathrm{Na})^{+}$by SIMS. The $\mathrm{C}$-terminal amino acid of 4 was identified as $\beta$-methylglutamic acid by carboxypeptidase ${ }^{11)}$ treatment. Selective acid hydrolysis of 4 with $0.25 \mathrm{M}$ $\mathrm{AcOH}$ gave aspartic acid, an acyl peptide (5) and tetrapeptide (6) (Scheme 4). The structure

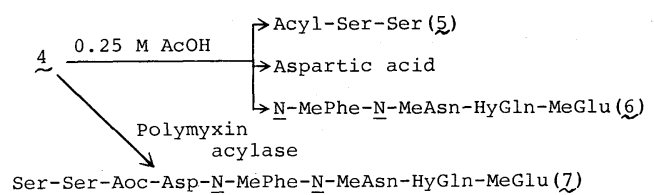

SCHEME 4.

of 5, which is 12-methyltridecanoyl-serylserine, was deduced from GC/MS analysis of the corresponding methyl ester as shown in Fig. 3. An amino acid analysis of 6 showed the presence of $N$-methylaspartic acid, $N$ methylphenylalanine, threo- $\beta$-methylglutamic acid and threo- $\beta$-hydroxyglutamic acid. From the ${ }^{1} \mathrm{H}$ NMR data $(\delta 6.80,6.89,7.30,7.42 \mathrm{ppm}$ in DMSO- $d_{6}$ at $400 \mathrm{MHz}$ ), 6 has two primary amides. The only possible positions for these are the $\gamma$-carboxyl groups of threo- $\beta$ hydroxyglutamic acid and $N$-methylaspartic acid, because a carboxypeptidase treatment of 6 gave $\beta$-methylglutamic acid but not $\beta$ methylglutamine. Three succesive Edman degradations revealed the sequence, $\mathrm{N}$-MePhe$N$-MeAsn-HyGln-MeGlu. The PTH amino acids were determined by GC/MS analysis ${ }^{12)}$ ( $m / z 296 \mathrm{M}^{+}$, PTH-N-MePhe; $m / z 263 \mathrm{M}^{+}$, PTH- $N$-MeAsn; $m / z 279 \mathrm{M}^{+}$, PTH-HyGln). Treatment of $\mathbf{4}$ with polymyxin acylase ${ }^{13)}$ gave a deacyl open chain acid (7) (Scheme 4). An Edman degradation of 7 clarified the sequence

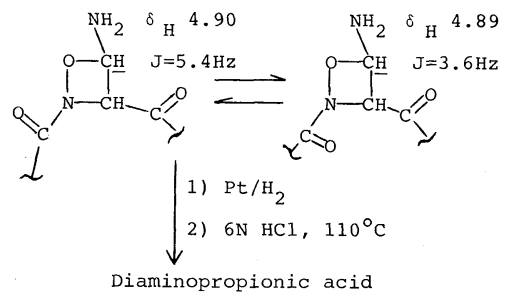

FIG. 2.

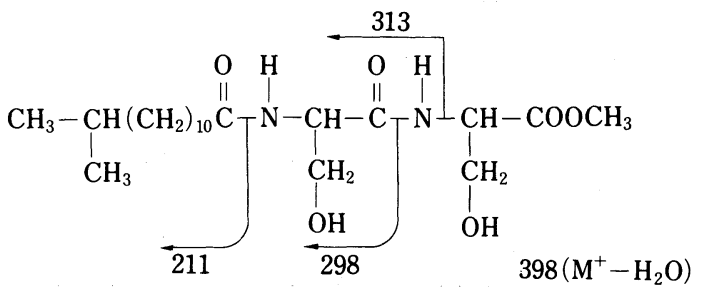

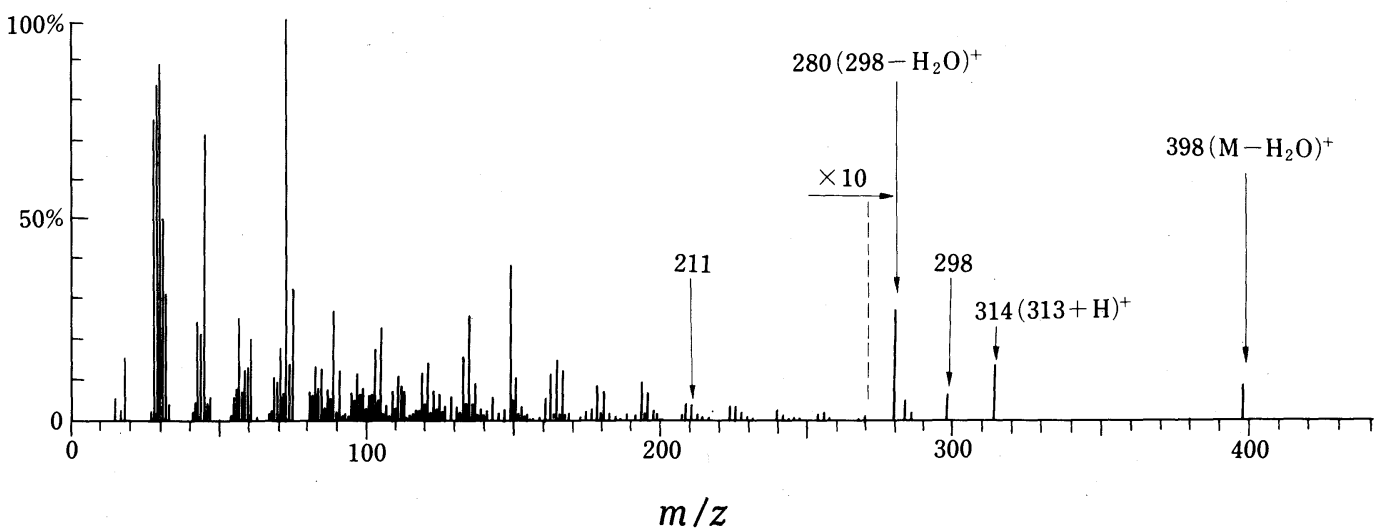

FIG. 3. GC/EIMS Spectrum of the Methyl Ester of Acyl Peptide 5. 

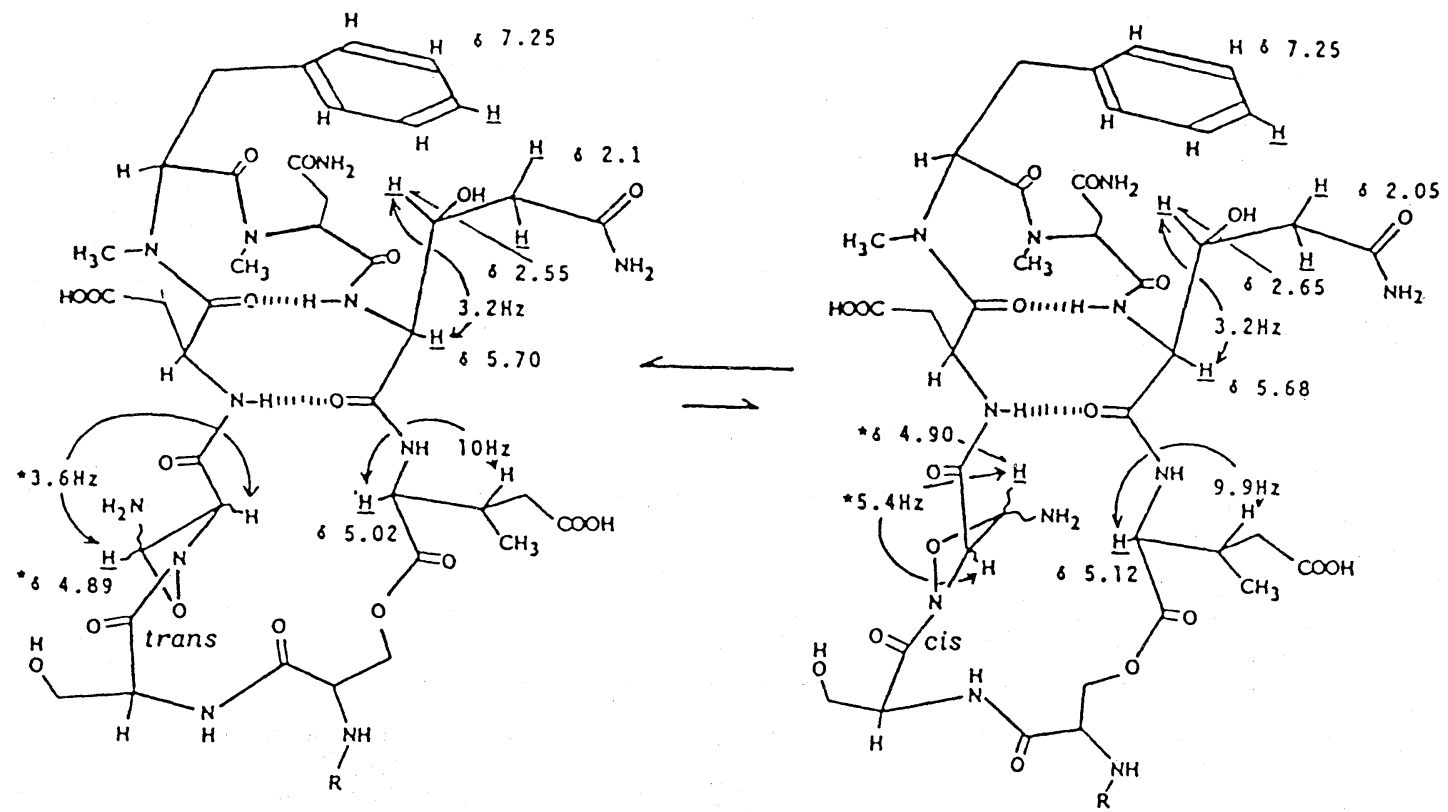

FIG. 4. Two Stable Conformations of Neopeptin A (1).

${ }^{1} \mathrm{H}$ NMR was measured at $23^{\circ} \mathrm{C}$, asterisks showing measurement at $55^{\circ} \mathrm{C}$.

of three amino acids (1st step, PTH-Ser; 2nd step, PTH-Ser; 3rd step, an unknown peak in HPLC). In addition, 4 was analyzed by SIMS, and the assignment of the main fragment ions is shown in Scheme 3.

The position of lactone and the structure of neopeptins

The position of the lactone was determined by the chromic acid oxidation of $\mathbf{1}$ in acetic acid-pyridine, followed by acid hydrolysis that resulted in the recovery of one mole of serine but no threo- $\beta$-hydroxyglutamic acid. Borohydride reduction of $\mathbf{1}$ in water followed by acid hydrolysis resulted in the disappearance of $\beta$-methylglutamic acid. In consideration of the $\mathrm{pKa}^{\prime}$ (two $\mathrm{p} \mathrm{Ka}^{\prime}$ values existed between 5.9 and 4.0) of $\mathbf{1}$, the lactone position was concluded to be between one of the $\beta$-hydroxy groups of serine and the $\alpha$ carboxyl group of $\beta$-methylglutamic acid.

Treatment of $\mathbf{1}$ with polymyxin acylase gave deacyl neopeptin (8). An Edman degradation of 1 whose PTH amino acids were detected by HPLC (1st step, not detected; 2nd step, Ser; 3 rd step, an unknown peak). The data shows

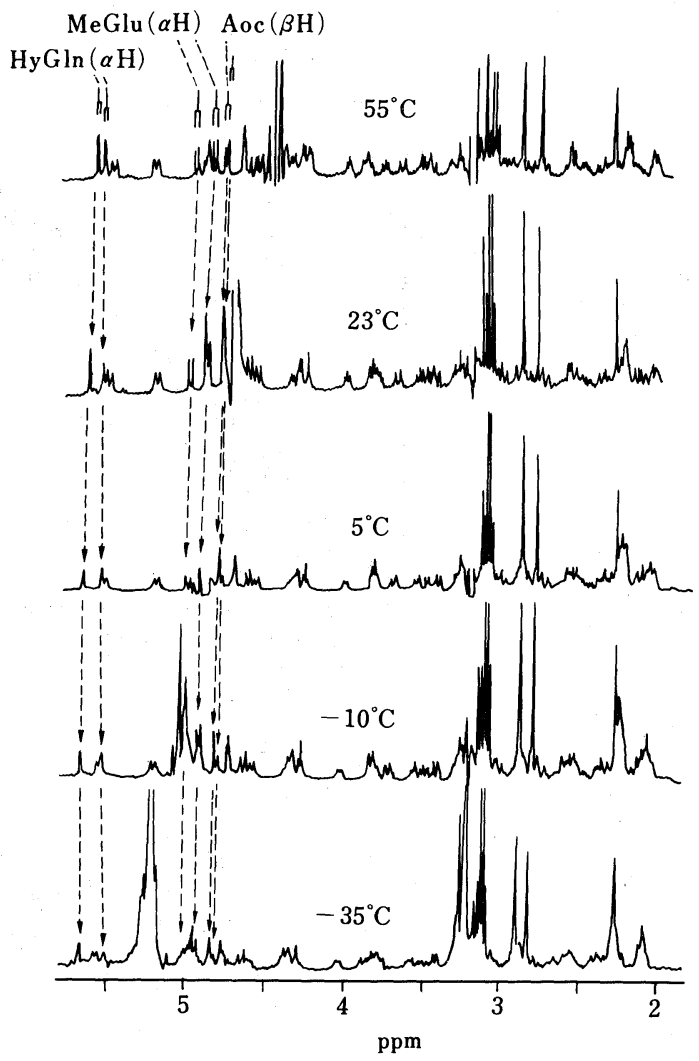

FIG. 5. $400 \mathrm{MHz}{ }^{1} \mathrm{H}$ NMR of Neopeptin A (1) at Various Temperatures in $\mathrm{MeOH}-d_{4}$. 
that acylated serine participated in the lactone formation.

Because treatment of $\mathbf{2}$ and $\mathbf{3}$ with polymyxin acylase gave $\mathbf{8}$, compounds $\mathbf{2}$ and $\mathbf{3}$ differ only at the fatty acid side chain. From the data described, we propose the structures 1, 2 and $\mathbf{3}$ for neopeptins A, B and C, respectively.

\section{Conformation of neopeptins}

The protons of some amino acids of 1 were observed as a pair of signals in ${ }^{1} \mathrm{H}$ NMR (in MeOH- $d_{4}$ at $400 \mathrm{MHz}$ ). Measurement of spectra at various temperatures $(55,23,5$, -10 and $-35^{\circ} \mathrm{C}$ in $\mathrm{MeOH}-d_{4}$ at $400 \mathrm{MHz}$ ) showed a continuous shift in the ratio of the pair of signals (ca. 1:1 to $3: 1$, Fig. 5). CPK model and Dreiding model examinations indicated that two stable conformations were possible concerning the cis and trans of the amide bond between serine and Aoc (Fig. 4). Analysis of the active hydrogen in $\mathbf{1}$ was done by SIMS: 1 in $\mathrm{H}_{2} \mathrm{O}, m / z 1176(\mathrm{M}+\mathrm{H})^{+}$; in $\mathrm{D}_{2} \mathrm{O}, m / z 1190(\mathrm{M}+\mathrm{D})^{+}$. The result shows that the exchange of two hydrogens of neopeptin with deuterium was slower than those of the 13 other active hydrogens, indicating the presence of two intramolecular hydrogen bonds in 1. ${ }^{1} \mathrm{H}$ NMR (2D NMR COSY ${ }^{14)}$ in $\left.\mathrm{MeOH}-d_{4}\right)$ showed a pair of two $\alpha$ pro-

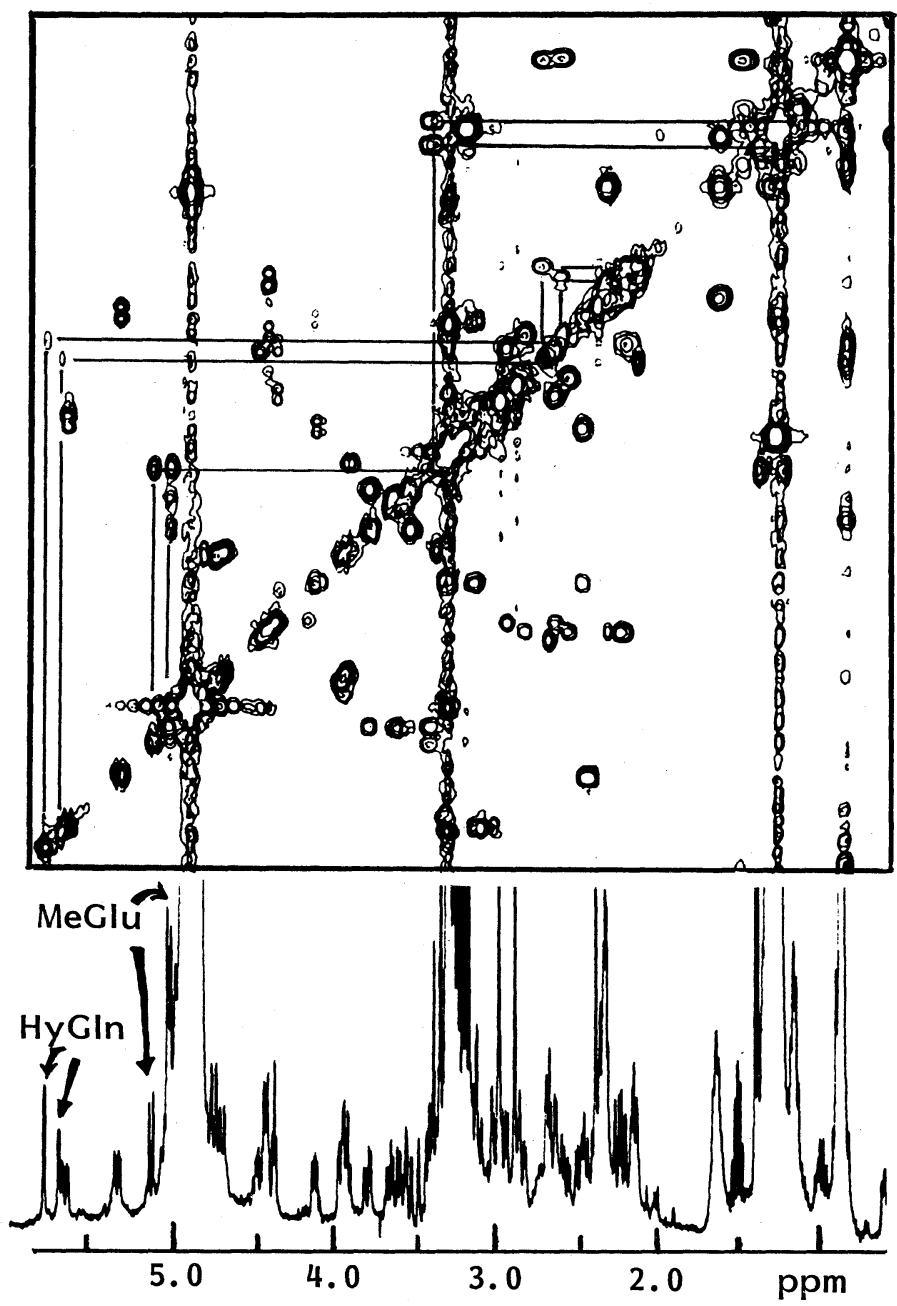

FIG. 6. ${ }^{1} \mathrm{H}-{ }^{1} \mathrm{H}$ COSY Spectrum of Neopeptin A (1).

Arrows show protons of each amino acid residue. 
Table I. Inhibition of Cell Wall Glycan Synthesis by Neopeptins

\begin{tabular}{cccc}
\hline & & $\mathrm{ID}_{50}(\mu \mathrm{g} / \mathrm{ml})$ & \\
\cline { 2 - 4 } Enzyme & Neopeptin A & Neopeptin B & Neopeptin C \\
\hline $\begin{array}{c}\text { B-1,3-Glucan synthetase } \\
(\text { S. cerevisiae }) \\
\begin{array}{c}\text { Mannoprotein synthetase } \\
(\text { S. cerevisiae })\end{array}\end{array}$ & 300 & 300 & 300 \\
\hline
\end{tabular}

Table II. Antimicrobial Activity of Neopeptins

\begin{tabular}{lccc}
\hline \multirow{2}{*}{ Test organism } & \multicolumn{3}{c}{ Diameter of inhibition zone (mm) } \\
\cline { 2 - 4 } & Neopeptin A & Neopeptin B & Neopeptin C \\
\hline Cochliobolus miyabeanus IFO 5277 & 20 & 20 & 20 \\
Pyricularia oryzae IFO 7513 & 23 & 21 & 27 \\
Glomerella cingulata IFO 9762 & 24 & 21 & 25 \\
\hline
\end{tabular}

Paper disks (diameter $8 \mathrm{~mm}$ ) were used containing $4 \mu \mathrm{g} /$ disk of neopeptins.

tons at $\delta 5.02(\mathrm{~d}, J=10 \mathrm{~Hz}$, the $\alpha$ proton of the major conformer, MeGlu), $\delta 5.12(\mathrm{~d}, J=$ $9.9 \mathrm{~Hz}$, the $\alpha$ proton of the minor conformer, MeGlu), $\delta 5.68(\mathrm{~d}, J=3.2 \mathrm{~Hz}$, the $\alpha$ proton of the minor conformer coupled with the $\beta$ proton at $\delta 2.65, \mathrm{HyGln})$, and $\delta 5.70(\mathrm{~d}, J=$ $3.2 \mathrm{~Hz}$, the $\alpha$ proton of the major conformer coupled with the $\beta$ proton at $\delta 2.55, \mathrm{HyGln}$ ) (Fig. 6). Therefore, another doublet pair, which could not be observed owing to overlapping of the solvent peak at $23^{\circ} \mathrm{C}$, should be assigned to the $\beta$ protons of Aoc $[\delta 4.89(\mathrm{~d}, J=3.6 \mathrm{~Hz}$, coupled with the $\alpha$ proton at $\delta 4.58$, major conformer), $\delta 4.90$ (d, $J=5.4 \mathrm{~Hz}$, coupled with the $\alpha$ proton at $\delta 4.5$, minor conformer), $55^{\circ} \mathrm{C}$, WEFT, in $\mathrm{MeOH}-d_{4}$ at $400 \mathrm{MHz}$. Figure 4 illustrates the remarkable shielding of the $\beta$ proton of HyGln by a phenyl groups, two intramolecular hydrogen bonds in two stable conformations, and a pair of signals of the ${ }^{1} \mathrm{H}$ NMR. The conformation of structurally related lipopeptin $\mathrm{A}^{7)}$ may be similar to those of neopeptin $\mathrm{A}$. The relative position of two $\mathrm{N}$-methyls of lipopeptin A coincided with those of neopeptin A. Therefore, the position of the two hydrogen bonds in lipopeptin $\mathrm{A}$ is considered to be similar to that of neopeptin A.

\section{Biological activity}

As shown in Table I, neopeptins A (1), B (2) and $\mathrm{C}$ (3) inhibited $\beta$-1,3-glucan synthetase and mannoprotein synthetase from Saccharomyces cerevisiae. ${ }^{1)}$ Chitin synthetase was not inhibited by $1 \mathrm{mg} / \mathrm{ml}$ of neopeptins. The antibiotics inhibited the growth of plant pathogenic fungi with swelling of the mycelium (Table II). Deacyl neopeptin (8) and the open chain acid (4) did not inhibit growth of the plant pathogenic fungi.

\section{DISCUSSION}

The fact that the deacyl derivative (8) inhibited neither the growth of plant pathogenic fungi nor glycan synthetase implies the importance of the fatty acyl side chain for biological activity. Most of the antibiotics, which are known to inhibit fungal cell wall glycan synthesis, (e.g., neopeptins, ${ }^{1)}$ lipopeptins, ${ }^{7)}$ papulacandin, ${ }^{15)}$ echinocandin ${ }^{16)}$ and flavomycin ${ }^{17)}$ ) have a long chain fatty acid. All these compounds contain both hydrophilic and lipophilic moieties. These structural characteristics may have some correlation to the structure of glycan synthetase which exist in lipid membrane. Because the open chain acid 
(4) does not inhibit the growth of fungi and glycan synthesis, the conformation of the cyclic peptide is also important for biological activity.

\section{EXPERIMENTAL}

Melting points were taken on a Yanagimoto micromelting point apparatus and are uncorrected. UV spectra were run on a Hitachi 220 A spectrophotometer and Ir spectra on a Shimadzu 521 grating infrared spectrometer. Optical rotations were determined with a Perkin-Elmer 141 polarimeter. Amino acid analyses were done with a JEOL JLC-6AH amino acid autoanalyzer. ${ }^{13} \mathrm{C}$ NMR spectra were run on a JEOL FX-100 instrument, and ${ }^{1} \mathrm{H}$ NMR spectra were run on FX-400 and GX-400 NMR spectrometers. Amino acid sequences were determined with a JEOL JAS-47K sequence analyzer, and an Applied Biosystems $470 \mathrm{~A}$ protein sequencer-spectra physics 8100 HPLC system. GC/MS were taken on a Hitachi RMU6MG (OV-1 column), and a HItachi M80. SIMS spectra were run on a Hitachi M80. HPLC were run on a Hitachi 635 A liquid chromatograph (Nucleosil $5 \mathrm{C}_{18}$ column), a Waters Prep LC/System 500 preparative liquid chromatograph (Prep PAK-500/C $\mathrm{C}_{18}$ column). High-voltage paper electrophoresis was done by a CAMAG HVE system, and potentiometric titration was carried out by a Metrohm Harisau E336 Potentiograph.

Neopeptin A (1), B (2) and C (3). Neopeptin A, B and C were isolated as described in the text.

Neopeptin A (1), amorphous white powder, $\mathrm{C}_{53} \mathrm{H}_{81} \mathrm{~N}_{11} \mathrm{O}_{19}$; IR: $v_{\max }^{\mathrm{KBr}} 1650,1530 \mathrm{~cm}^{-1}$ (amide bonds), $1740 \mathrm{~cm}^{-1}$ (lactone bond); $\mathrm{mp}>200^{\circ} \mathrm{C}\left(\mathrm{dec}\right.$.), $[\alpha]_{\mathrm{D}}^{20}-9.2$ (c 0.48, $\mathrm{MeOH}), m / z 1176(\mathrm{M}+\mathrm{H})^{+}, m / z 1198(\mathrm{M}+\mathrm{Na})^{+}$, $m / z 1214(\mathrm{M}+\mathrm{K})^{+}$(SIMS), pKa' 9.5 (basic group) between 5.9 and 4.0 (two acidic groups). Neopeptin B (2), amorphous white powder, $\mathrm{C}_{54} \mathrm{H}_{83} \mathrm{~N}_{11} \mathrm{O}_{19}, \mathrm{mp}>200^{\circ} \mathrm{C}$ (dec.), $[\alpha]_{\mathrm{D}}^{20}-28.5$ (c 0.12, MeOH), $m / z 1190(\mathrm{M}+\mathrm{H})^{+}$, $m / z \quad 1212(\mathrm{M}+\mathrm{Na})^{+}, m / z \quad 1228 \quad(\mathrm{M}+\mathrm{K})^{+} \quad$ (SIMS). Neopeptin C (3), amorphous white powder, mp $190 \sim 205^{\circ} \mathrm{C},[\alpha]_{\mathrm{D}}^{27}-12.8(c \quad 0.29, \mathrm{MeOH}),{ }^{18)} \mathrm{m} / \mathrm{z} 1162$ $(\mathrm{M}+\mathrm{H})^{+}, m / z 1184(\mathrm{M}+\mathrm{Na})^{+}$(SIMS).

Acid hydrolysis of neopeptin A (1). A solution of $400 \mathrm{mg}$ of 1 in $10 \mathrm{ml}$ of $6 \mathrm{~N} \mathrm{HCl}$ was heated at $110^{\circ} \mathrm{C}$ for $16 \mathrm{hr}$. The hydrolysate was extracted with $\mathrm{CHCl}_{3}$, and the $\mathrm{CHCl}_{3}$ layer was evaporated in vacuo. The residue was esterified with diazomethane to give $66 \mathrm{mg}$ of methyl 12-methyltridecanoate. The aqueous layer was extracted with $n-\mathrm{BuOH}$, and passed through $20 \mathrm{ml}$ of Dowex $50 \mathrm{~W} \times 2\left[\mathrm{H}^{+}\right]$, the effluent being lyophilized. The residue was passed through Dowex $50 \mathrm{~W} \times 2$ [pyridine], and the effluent was again lyophilized. It was further purified by cellulose chromatography with $n$-PrOH- $\mathrm{NH}_{4} \mathrm{OH}(7: 3)$ to give $11.8 \mathrm{mg}$ of $\mathrm{N}$ methylphenylalanine, $2.7 \mathrm{mg}$ of threo- $\beta$-methylglutamic acid, and $0.7 \mathrm{mg}$ of aspartic acid. Elution with $5 \%$ pyridine followed by purification by cellulose chromatography with $n$-PrOH-- $\mathrm{NH}_{4} \mathrm{OH}(7: 3)$ gave $17.4 \mathrm{mg}$ of $\mathrm{N}$-methylphenylalanine and a mixture of other amino acids. The other amino acids were further purified by preparative TLC with $75 \%$ phenol to give $6.5 \mathrm{mg}$ of $\mathrm{N}$-methylphenylalanine, $1.75 \mathrm{mg}$ of $N$-methylaspartic acid, $13.3 \mathrm{mg}$ of $\beta$-methylglutamic acid, $10.1 \mathrm{mg}$ of serine, $1.6 \mathrm{mg}$ of aspartic acid, and $0.8 \mathrm{mg}$ of hydroxyglutamic acid.

L- $N$-MePhe: $[\alpha]_{\mathrm{D}}^{22}+10.5\left(c \quad 0.6, \mathrm{H}_{2} \mathrm{O}\right) ; \quad$ L- $N$-MeAsp: $[\alpha]_{\mathrm{D}}^{22}+26.5(c 0.26,1 \mathrm{~N} \mathrm{HCl})$; L-threo- $\beta$-MeGlu: $[\alpha]_{\mathrm{D}}^{22}+5.4$ $(c 0.96,4 \mathrm{~N} \mathrm{HCl})$; L-Ser: $[\alpha]_{\mathrm{D}}^{23}-10.9\left(c 0.43, \mathrm{H}_{2} \mathrm{O}\right)$; L-Asp: $[\alpha]_{\mathrm{D}}^{20}+20.1(c 0.25,6 \mathrm{~N} \mathrm{HCl}) ; \mathrm{L}-$ threo- $\beta$-HyGlu: $[\alpha]_{\mathrm{D}}^{20}+15.6$ (c $0.08,1 \mathrm{~N} \mathrm{HCl})$.

Alkaline hydrolysis of neopeptin A (1). A solution of $1.9 \mathrm{mg}$ of neopeptin $\mathrm{A}$ in $1.9 \mathrm{ml}$ of $0.035 \mathrm{~N} \mathrm{NaOH}$ was allowed to stand for $12 \mathrm{hr}$ at $37^{\circ} \mathrm{C}$. The reaction mixture was passed through a column of $0.05 \mathrm{ml}$ of Dowex $50 \mathrm{~W} \times 8 \quad\left[\mathrm{H}^{+}\right]$. The effluent and the eluate with $2 \mathrm{~N}$ $\mathrm{NH}_{4} \mathrm{OH}$ were combined and lyophilized to give $1.5 \mathrm{mg}$ of a white powder of an open-chain acid (4): $m / z 1194$ $(\mathrm{M}+\mathrm{H})^{+}, m / z 1216(\mathrm{M}+\mathrm{Na})^{+}(\mathrm{SIMS})$.

Hydrolysis of $\mathbf{4}$ with carboxypeptidase. To a solution of $20 \mathrm{mg}$ of crude 4 in $800 \mu \mathrm{l}$ of buffer $\left(3 \mathrm{mM} \mathrm{CaCl} \mathrm{Cl}_{2}+25 \mathrm{~mm}\right.$ $\mathrm{NH}_{4} \mathrm{HCO}_{3}$ at $\mathrm{pH} 8$ ) was added $300 \mu \mathrm{l}$ of carboxypeptidase $(520 \mu \mathrm{g} / \mathrm{ml})$. The resulting solution was incubated for $14 \mathrm{hr}$ at $27^{\circ} \mathrm{C}$, before the reaction mixture was lyophilized. Purification by cellulose chromatography with $n-\mathrm{PrOH}-\mathrm{N}$ $\mathrm{NH}_{4} \mathrm{OH}(7: 3)$ gave $5 \mathrm{mg}$ of threo- $\beta$-methylglutamic acid and $12 \mathrm{mg}$ of the peptide $\left[m / z 1052(\mathrm{M}+\mathrm{H})^{+}, m / z 1074\right.$ $\left.(\mathrm{M}+\mathrm{Na})^{+}(\mathrm{SIMS})\right]$.

Selective acid hydrolysis of 4. A solution of $50 \mathrm{mg}$ of crude 4 in $0.25 \mathrm{M}$ acetic acid was refluxed for $24 \mathrm{hr}$. The reaction mixture was concentrated in vacuo and then lyophilized. The residue was passed through $3.5 \mathrm{ml}$ of Dowex $50 \mathrm{~W} \times 2\left[\mathrm{H}^{+}\right]$, and the effluent and washings were lyophilized to give $14.2 \mathrm{mg}$ of a white powder. The presence of aspartic acid was analyzed by TLC and an amino acid analyzer. Purification of $7.5 \mathrm{mg}$ of the white powder by HPLC using a $\mu$ Bondapak $\mathrm{C}_{18}$ column with $75 \%$ $\mathrm{MeOH}$ containing $0.15 \% \mathrm{AcOH}$ gave $0.9 \mathrm{mg}$ of the pure acyl peptide 5, which was esterified with diazomethane, and followed by GC/MS analysis. The eluate with $1 \mathrm{~N}$ $\mathrm{NH}_{4} \mathrm{OH}$ gave $21.3 \mathrm{mg}$ of a white powder after lyophilization. Purification by preparative TLC with a solvent system of $\mathrm{PrOH}$-pyridine- $\mathrm{AcOH}-\mathrm{H}_{2} \mathrm{O}$ (15:10:3:12) gave $4.2 \mathrm{mg}$ of a tetrapeptide (6), whose structure was determined by the analysis described in the text.

Hydrolysis of $\mathbf{4}$ with polymyxin acylase. To a solution of $10 \mathrm{mg}$ of 4 in a buffer $\left(3 \mathrm{mM} \mathrm{CaCl} \mathrm{Cl}_{2}+25 \mathrm{mM} \mathrm{NH}_{4} \mathrm{HCO}_{3}\right.$ at $\mathrm{pH}$ 7.8) was added $5 \mathrm{mg}$ of polymyxin acylase. The mixture was incubated for $17 \mathrm{hr}$ at $37^{\circ} \mathrm{C}$. The mixture was passed through $0.5 \mathrm{ml}$ of Dowex $50 \mathrm{~W} \times 2\left[\mathrm{H}^{+}\right]$, which 
was eluted by $1 \mathrm{~N} \mathrm{NH}_{4} \mathrm{OH}$ to give $8.7 \mathrm{mg}$ of a white powder after lyophilization. Purification by preparative TLC with a solvent system of $\mathrm{BuOH}-\mathrm{AcOH}-\mathrm{H}_{2} \mathrm{O}$ (4: $1: 2$ ) gave $1.2 \mathrm{mg}$ of 7 after passing through Dowex $50 \mathrm{~W} \times 2\left[\mathrm{H}^{+}\right]$and following by elution with $1 \mathrm{~N} \mathrm{NH} \mathrm{NH}_{4} \mathrm{OH}$.

Deacyl open-chain acid (7): $m / z 984(\mathrm{M}+\mathrm{H})^{+}, m / z$ $1006(\mathrm{M}+\mathrm{Na})^{+}(\mathrm{SIMS})$.

Chromic acid oxidation of 1. To a solution of $\mathrm{CrO}_{3}$ $(1.56 \mathrm{mg})$ in $\mathrm{AcOH}-\mathrm{H}_{2} \mathrm{O}$-pyridine $(47: 1.6: 1.6 \mu \mathrm{l})$ was added $1 \mathrm{mg}$ of 1 . The resulting mixture was stirred for $14 \mathrm{hr}$ at $27^{\circ} \mathrm{C}$. To the mixture was added water $(1.5 \mathrm{ml})$ before the solution was extracted four times with EtOAc. The extract was washed three times with water, dried over $\mathrm{Na}_{2} \mathrm{SO}_{4}$ and evaporated in vacuo to leave a residue. $\mathrm{MeOH}$ was added to the residue and the solution was evaporated under an $\mathrm{N}_{2}$ stream. A solution of the residue in $0.5 \mathrm{ml}$ of $6 \mathrm{~N} \mathrm{HCl}$ was heated at $110^{\circ} \mathrm{C}$ for $17 \mathrm{hr}$, and the hydrolysate was evaporated in vacuo. The disappearance of hydroxyglutamic acid and $1 \mathrm{~mol}$ of serine was analyzed by the amino acid analyzer.

Borohydride reduction of $\mathbf{1}$. To a solution of $5 \mathrm{mg}$ of $\mathbf{1}$ in $0.4 \mathrm{ml}$ of water was added $15 \mathrm{mg}$ of $\mathrm{NaBH}_{4}$ in $1.5 \mathrm{ml}$ of water. This mixture was stirred for $24 \mathrm{hr}$ and acidified with $10 \% \mathrm{AcOH}$. The residue was passed through $2 \mathrm{ml}$ of Dowex $50 \mathrm{~W} \times 2\left[\mathrm{H}^{+}\right]$, eluted with $1 \mathrm{~N} \mathrm{NH} \mathrm{NH}_{4} \mathrm{OH}$, and lyophilized to give a residue. A solution of this residue in $1 \mathrm{ml}$ of $6 \mathrm{~N} \mathrm{HCl}$ was heated at $110^{\circ} \mathrm{C}$ for $16 \mathrm{hr}$. The hydrolysate was evaporated in vacuo. The disappearance of methylglutamic acid was analyzed by the amino acid analyzer.

Biological assay. $\beta-1,3-$ Glucan synthesis was assayed using Saccharomyces cerevisiae (GS-1-36) particulate enzyme and UDP-[U- $\left.{ }^{14} \mathrm{C}\right]$ glucose as the substrate. ${ }^{19)}$ Mannoprotein synthesis was assayed using the same preparation of $S$. cerevisiae particulate enzyme, with GDP-[U- $\left.{ }^{14} \mathrm{C}\right] \mathrm{mannose}$ as the substrate. Chitin synthesis was assayed using Piricularia oryzae particulate enzyme and UDP-[U- $\left.{ }^{14} \mathrm{C}\right]$ GlcNAc. ${ }^{20)}$

Antimicrobial activity was assayed by the conventional paper-disc method using potato-sucrose agar medium.

Acknowledgments. We are grateful to Professor Y. Izumi, Osaka University, for his gift of L-threo- $\beta$ methylglutamic acid and L-erythro- $\beta$-methylglutamic acid, and to Professor Y. Kimura, Mukogawa Woman's University, for the gift of polymyxin acylase. We thank Professor H. Hayashi, Gumma University, and JEOL Co., Ltd. for an amino acid sequence analysis.

\section{REFERENCES AND NOTES}

1) a) T. Satomi, H. Kusakabe, G. Nakamura, T. Nishio, M. Uramoto and K. Isono, Agric. Biol. Chem., 46, 2621 (1982); b) K. Isono, M. Uramoto and M. Ubukata, IUPAC Pesticide Chemistry, Pergamon Press, 1983, p. 63.

2) A preliminary paper on this work has appeared: $\mathbf{M}$. Ubukata, M. Uramoto and K. Isono, Tetrahedron Lett., 25, 423 (1984).

3) M. Ebata, Y. Takahashi and H. Otsuka, Bull. Chem. Soc. Jpn., 39, 2535 (1966).

4) T. Harada, M. Imaida and Y. Izumi, Bull. Chem. Soc. Jpn., 44, 1419 (1971).

5) a) T. Kaneko, Y. Yoshida and H. Katsura, Nihon Kagaku Zasshi, 80, 316 (1959); b) T. Shiba and Y. Mukunoki, J. Antibiot., 28, 561 (1975).

6) H. Vanderhaege and G. Parmentier, J. Am. Chem. Soc., 82, 4414 (1960).

7) M. Nishii, T. Kihara, K. Isono, T. Higashijima, T. Miyazawa, S. K. Sethi and J. A. McCloskey, Tetrahedron Lett., 21, 4627 (1980).

8) R. Ryhage and E. Stenhagen, Arkiv. Kemi., 15, 291 (1968).

9) J. B. Stothers, "Carbon-13 NMR Spectroscopy," Academic Press, New York, 1972, p. 342.

10) T. J. Batterham, "NMR Spectra of Simple Heterocycles," Wiley-Interscience, New York, 1973, p. 142.

11) Y. Narahashi and K. Yoda, J. Biochemistry, 86, 683 (1979).

12) P. Edman, "Protein Sequence Determination," ed. by J. W. Needleman, Springer, Berlin, 1975, p. 232.

13) T. Suzuki, Y. Kimura and K. Iwatare, Japan Patent 12101/1966 (July 4).

14) a) A. Bax, R. Freeman and G. Morris, J. Magn. Reson., 42, 164 (1981); b) A. Bax and R. Freeman, ibid, 44, 542 (1983).

15) P. Traxler, H. Fritz and W. J. Richter, Helv. Chim. Acta, 60, 578 (1977).

16) C. Keller-Juslen, M. Kuhn, H. R. Loosli, T. J. Petcher, H. P. Weber and A. von Wartburg, Tetrahedron Lett., 4147 (1976).

17) a) M. Fevre, J. Gen. Microb., 129, 3007 (1983); b) P. Welzel, F. J. Witteler, D. Muller and W. Riemer, Angew. Chem., Int. Ed. Engl., 20, 121 (1981).

18) The optical rotation $\left([\alpha]_{\mathrm{D}}^{27}-3.7\right)$ in ref. 2 was revised.

19) E. M. Shematek, J. A. Braatz and E. Cabib, J. Biol. Chem., 255, 888 (1980).

20) N. Ohta, K. Kakiki and T. Misato, Agric. Biol. Chem., 34, 1224 (1970). 